\title{
Toxicity Evaluation of a Municipal Dump Leachate Using Zebrafish Acute Tests
}

\author{
C. L. S. Sisinno, ${ }^{1}$ E. C. Oliveira-Filho, ${ }^{2}$ M. C. Dufrayer, ${ }^{1}$ J. C. Moreira, \\ F. J. R. Paumgartten ${ }^{2}$
}

\begin{abstract}
'Laboratory of Toxicology, Environmental Assessment, Center of Worker's Health and Human Ecology, National School for Public Health, Oswaldo Cruz Foundation (FIOCRUZ), Rua Leopoldo Bulhões 1480,21041-210, Rio de Janeiro, RJ - Brazil ${ }^{2}$ Laboratory of Environmental Toxicology, Department of Biological Sciences, National School for Public Health, Oswaldo Cruz Foundation (FIOCRUZ), Brazil
\end{abstract}

Received: 6 June 1999/Accepted: 17 October 1999

The problems related to urban waste disposal in Brazil are critical since available areas are few and located in the vicinity of populated areas and close to water resources mangroves, forests and rivers.

Niterói is one of the tourist cities in the State of Rio de Janeiro (Brazil) and is considered to be a city of a high standard of living. However, the fate of the waste produced in this city is not well managed, being disposed at Morro do Céu Dump. The disposal site, located in a valley of several springs and a small river, the MataPaca River, has been in operation since 1983, receiving around 550 tons/day of urban waste. Analysis of the leachate produced at Morro do Céu Dump showed the presence of some contaminants such as heavy metals and PAHs (Sisinno and Moreira 1996; Sisinno et al. 1998). Part of the leachate infiltrates into the soil and another part flows directly into the river. Mata-Paca River is used for the irrigation of some local plantations and flows into Guanabara Bay, an important ecosystem of Rio de Janeiro State.

Because of most hazardous substances found in leachate composition, toxicity testing of leachates has been carried out by many studies (Atwater et al. 1983; Cheung et al. 1993; Clément et al. 1996; Wong 1989). However, in Brazil, this kind of evaluation is commonly applied to industrial effluents to control the efficiency of the plants, because in many cases, leachate produced at waste disposal sites is discharged into water streams without control.

The aim of this study was to evaluate acute toxicity (48-hr) of the leachate collected at Morro do Céu Dump to Brachydanio reri o(zebrafish). The leachate was treated under different conditions to compare the toxicity of pure samples with treated ones.

\section{MATERIALS AND METHODS}

Leachate samples were collected once a month, during a dry (July/September/November 1998) and wet (January/February/March/April 1999) period in Rio de Janeiro State. The sampling point chosen was a stream where 
the leachate produced in the different areas of Morro do Céu Dump is mixed before being discharged into Mata-Paca river.

The leachate was analysed for $\mathrm{pH}$ (Analyser 300M, $\mathrm{pH}$ electrode), DO (Digimed DM4 dissolved oxygen meter), conductivity (Analion C-702 conductivity meter), hardness, alkalinity, BOD, COD and chloride according to Standard Methods (APHA 1985).

The organism chosen for this biological evaluation was zebrafish, Brachydanio rerio, Cyprinidae, purchased from a commercial supplier in Rio de Janeiro, weighing 0.2 to $0.4 \mathrm{~g}$ and having an average length of 2.0 to $3.0 \mathrm{~cm}$. Brachydanio rerio is one of the most common species used to perform acute toxicity tests in Brazil according to Brazilian (SEMA 1988) and Rio de Janeiro State (FEEMA 1994) standard procedures.

Acute toxicity tests (static method) were carried out as standardized by the Associação Brasileira de Normas Técnicas (ABNT 1993). Briefly, 10 adult fishes were placed in $3.000 \mathrm{~mL}$ glass beakers and mortality was evaluated after 24 and 48 hours of exposure, dead fishes being removed. Negative control (synthetic soft water) beakers were included. In each test with pure leachate, a positive control test was performed to evaluate the sensitivity of fishes. Room temperature $\left(25 \pm 1^{\circ} \mathrm{C}\right)$ and light/dark cycle $(16 \mathrm{hr}$ light $/ 8 \mathrm{hr}$ dark) were kept constant. LC50 values and their 95\% confidence limits were calculated using Trimmed Spearman-Karber Method, available in computer software (Hamilton et al. 1977).

Synthetic soft water was prepared to be used in the dilutions with $\mathrm{NaHCO}_{3}(48$ $\mathrm{mg}), \mathrm{CaSO}_{4} \cdot 2 \mathrm{H}_{2} \mathrm{O}(30 \mathrm{mg}), \mathrm{MgSO}_{4} \cdot 7 \mathrm{H}_{2} \mathrm{O}(614 \mathrm{mg})$, and $\mathrm{KCl}(2 \mathrm{mg})$, dissolved in $1.000 \mathrm{~mL}$ of distilled water, resulting in a hardness of $40-48 \mathrm{mg} / \mathrm{L} \mathrm{CaCO}_{3}$ and $\mathrm{pH}$ of 7.2-7.6 (ABNT 1993).

For each toxicity test, leachate samples both pure and treated were used. Tests using pure leachate samples were performed immediately after the arrival of the samples to the laboratory. The other tests were performed after each treatment. The treatments were: EDTA $0.1 M 5 \%$ v/v in $2.000 \mathrm{~mL}$ of leachate; aeration; $\mathrm{Al}_{2}\left(\mathrm{SO}_{4}\right)_{3} .18 \mathrm{H}_{2} \mathrm{O}$, alum, (Merck) $2 \mathrm{~g} / \mathrm{L}$ and $4 \mathrm{~g} / \mathrm{L}$, as performed by Wong (1989); maintenance during one week in ambient $\left(25 \pm^{\circ} \mathrm{C}\right)$ and cool $\left(4^{\circ} \mathrm{C}\right)$ temperature; alum $4 \mathrm{~g} / \mathrm{L}$ EDTA $0.1 M$, and air.

The solutions of alum $2 \mathrm{~g} / \mathrm{L}$ and $4 \mathrm{~g} / \mathrm{L}$ were prepared and added to samples of pure leachate. Tests using alum $4 \mathrm{~g} / \mathrm{L}$ in pure leachate samples were performed after a time reaction of 30minutes (sample 04) and 48 hours (samples 05,06 and 07). After reaction, supernatant was used for the test dilutions. A negative control using alum in synthetic soft water at the same conditions of leachate tests was conducted to evaluate alum toxicity. Due to hydrolysis of $\mathrm{Al}^{+3}$ ion, the $\mathrm{pH}$ was adjusted, carefully to $\mathrm{pH} 7.0$ using $\mathrm{NaOH} 1 N$. 


\section{RESULTS AND DISCUSSION}

Values of physico-chemical parameters of pure Morro do Céu leachate samples are shown in Table 1. The lowest and the highest values found in leachate analysis since 1994 (Sisinno and Moreira 1996; Sisinno et al. 1998), including the present results, are shown.

The $\mathrm{pH}$ values between 7.7-8.1 indicate the predominance of leachate from waste in advanced stages of decomposition (Philips et al. 1984). The high BOD and COD values indicate a high amount of organic compounds that are being discharged into the river, contributing to its eutrofization. DO values observed, even during the wet period, are not higher than $0.7 \mathrm{mg} / \mathrm{L}$.

Table 1. Physico-chemical characteristics of pure Morro do Céu leachate samples. Lowest and highest values found during 1994-1999.

\begin{tabular}{cc}
\hline PARAMETER & VALUES \\
\hline $\mathrm{pH}$ & $7.7-8.1$ \\
Conductivity $(\mathrm{mS})$ & $3.09-6.20$ \\
Alkalinity $\left(\mathrm{CaCO}_{3}\right)(\mathrm{mg} / \mathrm{L})$ & $212-372$ \\
Hardness $\left(\mathrm{CaCO}_{3}\right)(\mathrm{mg} / \mathrm{L})$ & $60-95$ \\
Chloride $(\mathrm{mg} / \mathrm{L})$ & $22-42$ \\
BOD $(\mathrm{mg} / \mathrm{L})$ & $2.800-4.000$ \\
COD $(\mathrm{mg} / \mathrm{L})$ & $5.200-11.500$ \\
DO $(\mathrm{mg} / \mathrm{L})$ & $0.2-0.7$ \\
\hline
\end{tabular}

Values of LC50 of pure Morro do Céu leachate samples presented in Table 2 indicate high acute toxicity to Brachydanio rerio in 24 hours of exposure. They don't show a correlation between toxicity and periods of sampling (dry or wet). This fact may be related to similar rainfall registers, observed during the two periods of study, according to National Institute of Meteorology from Brazil.

This monitoring showed that LC50 values of pure leachate samples are included in a range of 2.2 to $5.7 \%(\mathrm{v} / \mathrm{v})$, indicating low variation between the obtained results in the different samplings.

The values of LC50 for 24 hours are the same for 48 hours, indicating that pure leachate acute toxicity was expressed in the first 24 hours. Most likely, the toxicants were degraded or transformed. A similar result was obtained by Wong (1989).

The data of acute toxicity (96-hr) of positive control (potassium dichromate in synthetic soft water) to Brachydanio rerio were in a range of $83.4-117.3 \mathrm{mg} / \mathrm{L}$. These values are according to previous results in our laboratory and with Rio de Janeiro State standard procedures (FEEMA 1994). 
Table 2. Acute toxicities of pure Morro do Céu leachate samples to Brachydanio rerio after 24 and 48 hours. Data are revealed as LC50 (\% v/v) values and respective confidence limits $95 \%$.

\begin{tabular}{cccc}
\hline $\begin{array}{c}\text { PURE } \\
\text { SAMPLE }\end{array}$ & SAMPLING MONTH & $\begin{array}{c}\text { LC50 }(\% \mathrm{v} / \mathrm{v}) \\
(24-\mathrm{hr})\end{array}$ & $\begin{array}{c}\text { LC50 }(\% \mathrm{v} / \mathrm{v}) \\
(48-\mathrm{hr})\end{array}$ \\
\hline 01 & July 98 & 2.2 & 2.2 \\
& & $1.7-2.8$ & $1.7-2.8$ \\
02 & September 98 & 4.1 & 4.1 \\
& & $3.4-4.8$ & $3.4-4.8$ \\
03 & November 98 & 5.7 & 5.7 \\
& & $4.7-7.0$ & $4.7-7.0$ \\
04 & January 99 & 3.3 & 3.3 \\
& & $2.8-3.8$ & $2.8-3.8$ \\
05 & February 99 & 3.3 & 3.3 \\
& & $2.8-3.8$ & $2.8-3.8$ \\
06 & March 99 & 2.6 & 2.6 \\
& & $1.9-3.4$ & $1.9-3.4$ \\
07 & April 99 & 3.2 & 3.2 \\
& & $2.4-4.3$ & $2.4-4.3$ \\
\hline
\end{tabular}

Comparison of acute toxicities of pure and treated Morro do Céu leachate samples are showed in Table 3. In order to estimate oxygen influence, a test was carried out with pure aerated and non aerated leachate samples. It was observed that the inclusion of air didn't improve the results.

EDTA is a strong chelating agent, used in two samples of this experiment (samples 01 and 02). Results of treatment using EDTA 0.1M, comparing with its respective pure leachate samples, didn't show a significant efficiency.

One of the physico-chemical preservation methods of samples is maintenance in cool temperature $\left(4^{\circ} \mathrm{C}\right)$. Sample 04 was kept in ambient temperature, while sample 05 was kept in $4^{\circ} \mathrm{C}$, during the same period (one week). Both results were similar to its respective pure leachate samples.

Alum is widely used in the floculation-sedimentation of water and wastewater treatment process. For treatment using alum, the test conducted with $2 \mathrm{~g} / \mathrm{L}$ has shown a significative reduction in toxicity. Samples treated with $4 \mathrm{~g} / \mathrm{L}$, however, even in aerated and non aerated conditions (samples 04, 05, 06, and 07) have shown toxicity reduction. A test using alum in synthetic soft water, performed in the same dilutions of leachate tests, were not lethal to fishes, indicating a low amount of free $\mathrm{Al}^{+3}$ in solution.

Only sample 04 treated with alum $4 \mathrm{~g} / \mathrm{L}$, showed a significant difference between the LC 50 of 24 to $48 \mathrm{hr}$. This indicated an increase in toxicity for $48 \mathrm{hr}$, probably because of a short time of reaction $(30 \mathrm{~min})$. 
Table 3. Comparison of acute toxicities of pure and treated Morro do Céu leachate samples to Brachydanio rerio after 24 and 48 hours. Data are showed as LC50 (\% v/v) values and respective confidence limits $95 \%$.

\begin{tabular}{|c|c|c|c|}
\hline SAMPLE & TREATMENT & $\begin{array}{c}\text { LC } 50(\% \mathrm{v} / \mathrm{v}) \\
(24-\mathrm{hr}) \\
\end{array}$ & $\begin{array}{c}\text { LC } 50(\% \mathrm{v} / \mathrm{v}) \\
(48-\mathrm{hr})\end{array}$ \\
\hline \multirow[t]{2}{*}{01} & None & $\begin{array}{c}2.2 \\
1.7-2.8\end{array}$ & $\begin{array}{c}2.2 \\
1.7-2.8\end{array}$ \\
\hline & EDTA $0.1 M$ & $\begin{array}{c}3.3 \\
2.8-3.8\end{array}$ & $\begin{array}{c}3.3 \\
2.8-3.3\end{array}$ \\
\hline \multirow[t]{4}{*}{02} & None & 4.1 & 4.1 \\
\hline & & $3.4-4.8$ & $3.4-4.8$ \\
\hline & EDTA $0.1 M$ /air & 3.3 & 3.3 \\
\hline & & $2.8-3.8$ & $2.8-3.8$ \\
\hline \multirow[t]{4}{*}{03} & None & 5.7 & 5.7 \\
\hline & & $4.7-7.0$ & $4.7-7.0$ \\
\hline & $\mathrm{Al}_{2}\left(\mathrm{SO}_{4}\right)_{3} 2 \mathrm{~g} / \mathrm{L}$ & 13.2 & 13.2 \\
\hline & & $11.6-15.1$ & $11.6-15.1$ \\
\hline \multirow[t]{6}{*}{04} & None & 3.3 & 3.3 \\
\hline & & $2.8-3.8$ & $2.8-3.8$ \\
\hline & Kept in ambient & 3.3 & 3.3 \\
\hline & temperature & $2.8-3.8$ & $2.8-3.8$ \\
\hline & $\mathrm{Al}_{2}\left(\mathrm{SO}_{4}\right)_{3} 4 \mathrm{~g} / \mathrm{L}^{*}$ & 31.5 & 17.7 \\
\hline & & $25.3-39.2$ & $12.4-25.3$ \\
\hline \multirow[t]{6}{*}{05} & None & 3.3 & 3.3 \\
\hline & & $2,8-3.8$ & $2.8-3.8$ \\
\hline & $\mathrm{Al}_{2}\left(\mathrm{SO}_{4}\right)_{3} 4 \mathrm{~g} / \mathrm{L}^{* *}$ & 32.6 & 32.6 \\
\hline & & $28.0-38.0$ & $28.0-38.0$ \\
\hline & Kept in $4^{\circ} \mathrm{C}$ & 4.4 & 4.1 \\
\hline & & $3.6-5.3$ & $3.4-4.8$ \\
\hline \multirow[t]{6}{*}{06} & None & 2.6 & 2.6 \\
\hline & & $1.9-3.4$ & $1.9-3.4$ \\
\hline & Aerated & 3.1 & 2.4 \\
\hline & & $2.4-4.0$ & $1.7-3.3$ \\
\hline & $\mathrm{Al}_{2}\left(\mathrm{SO}_{4}\right)_{3} 4 \mathrm{~g} / \mathrm{L}^{* *} / \mathrm{air}$ & 32.6 & 32.6 \\
\hline & & $28.0-38.0$ & $28.0-38.0$ \\
\hline \multirow[t]{4}{*}{07} & None & 3.2 & 3.2 \\
\hline & & $2.4-4.3$ & $2.4-4.3$ \\
\hline & $\mathrm{Al}_{2}\left(\mathrm{SO}_{4}\right)_{3} 4 \mathrm{~g} / \mathrm{L}^{* *} /$ & 15.8 & 15.8 \\
\hline & EDTA $0.1 M /$ air & $13.1-19.2$ & $13.1-19.2$ \\
\hline
\end{tabular}

* test performed after a time of reaction of 30 minutes.

** test performed after a time of reaction of 48 hours. 
The test using alum $4 \mathrm{~g} / \mathrm{L}$, EDTA $0.1 M$ and air (sample 07) showed a decreasing efficiency, as compared to treatment using only alum $4 \mathrm{~g} / \mathrm{L}$ The result produced was probably because of EDTA toxicity (Richardson and Gangolli 1994).

Treatment using alum $4 \mathrm{~g} / \mathrm{L}$ was the better. This was related to the decrease of acute toxicity of Morro do Céu leachate to $B$. rerio. Comparing the results, better treatment was achieved in samples 05 and 06. It can be observed that LC50 $24 \mathrm{hr}$ of pure leachate samples of 3.3\% (sample 05) and 2.6\% (sample 06), after this treatment, went up to $32.6 \%$ (24 and $48 \mathrm{hr}$ ), resulting in a sign\&ant improvement.

Although B. rerio 48-hr acute tests have demonstrated high sensitivity to leachate toxicity evaluation, was recommended the performance of a monitoring using chronic tests to estimate with more safety the effects of this complex mixture to aquatic organisms.

The results presented in this work indicate that Morro do Céu leachate is a highly toxic effluent that is being discharged into an important aquatic ecosystem, representing a potential hazard to aquatic species. This emission should be regulated.

Acknowledgments This work was supported by grants from FAPERJ (Rio de Janeiro State Agency for Supporting Research)/Oswaldo Cruz Foundation Acoord. Authors thanks for Dr. Annibal Duarte Pereira Netto by the support on chemical analysis.

\section{REFERENCES}

ABNT - Associação Brasileira de Normas Técnicas (1993) Água - ensaio de toxicidade aguda corn peixes - Parte I - sistema estático, NBR 12.714, Rio de Janeiro, ABNT, 15 p

APHA - American Public Heath Association (1985) Standard methods for the examination of water and wastewater. APHA/AWWA/WPCF, Washington D.C.

Atwater JW, Jasper S, Mavinic DS, Koch FA (1983) Experiments using Daphnia to measure landfill leachate toxicity. Water Res 17: 1855- 1861

Cheung KC, Chu LM, Wong MH (1993) Toxic effect of landfill leachate on microalgae. Wat Air Soil Pollut 69:337-349

Clement B, Persoone G, Janssen RC, Le Dû-Delepiene A (1996) Estimation of the hazard of landfills through toxicity testing of leachates - I. Determination of leachate toxicity with a battery of acute tests. Chemosphere 33:2303-2320

FEEMA (1994) Método de determinação do efeito agudo letal causado por efluentes líquidos em peixes da espécie Brachydanio rerio - Método Estático. MF 456.RO. Diário Oficial do Estado do Rio de Janeiro. 27 de abril, p 18-20

Hamilton MA, Russo RC, Thurston RV (1977) Trimmed Spearman-Karber 
method for estimating median lethal concentrations in toxicity bioassays. Environ Sci Technol 11:714-719

Philips PA, Freestone NP, Hall RS (1994) Dealing with leachate. Chem in Britain 30:828-830

Richardson ML, Gangolli S (1994) The Dictionary of Substances and Their Effects, vol 4. The Royal Society of Chemistry, England, p 201

SEMA - Secretaria Especial do Meio Ambiente (1988) Manual de testes para avaliação da ecotoxicidade de agentes químicos. Avaliação da toxicidade aguda para peixes (D.3.1), Brasília D.F.

Sisinno CLS, Moreira JC (1996) Avaliação da contaminação e poluição ambiental na área de influência do aterro controlado do Morro do Céu, Niterói, Brasil Cad Saúde Pub 12:515-523

Sisinno CLS, Moreira JC, Torres JPM (1998) Environmental health assessment at two waste disposal sites at Niterói, state of Rio de Janeiro, Brazil. $1^{\text {st } W o r l d ~}$ Cong of Health and Urban Environ, 6- 10 july 1998, p 130

Wong MH (1989) Toxicity test of landfill leachate using Sarotherodon mossambicus (freshwater fish). Ecotoxicol Environ Safety 17: 149-156 